\title{
High Frequency Micropropagation of Aloe vera L. Burm. f. as a Low Cost Option Towards Commercialization
}

\author{
Anusree Das, Priyanka Mukherjee and Timir Baran Jha \\ Plant Biotechnology Laboratory, Department of Botany, Presidency College, \\ Kolkata, India \\ Key words: Aloe vera, Bitter cultivar, Micropropagation, Cost analysis
}

\begin{abstract}
An efficient micropropagation protocol has been developed using shoot apical meristem as explants in a high barbaloin content 'bitter' cultivar of Aloe vera L. The protocol involves induction, multiplication and in vitro rooting of the regenerated shoots and their acclimation under ex vitro conditions. $35.5 \mu \mathrm{M}$ BAP and $9.8 \mu \mathrm{M}$ IBA in combination with $81.4 \mu \mathrm{M}$ adenine sulphate proved optimum for shoot bud induction. Combination of $8.87 \mu \mathrm{M}$ BAP and $2.46 \mu \mathrm{M}$ IBA produced highest number of shoot buds $(22.0 \pm 0.14)$ and enhanced bud proliferation within one - two weeks after first subculture. For induction of in vitro rooting, Aloe gel as an alternative to conventional rooting medium used for the first time resulted in $100 \%$ rooting and highest number of roots per culture $(10.90 \pm 0.17)$. The plantlets were successfully hardened. Cent per cent plants survived in the field condition. Chromosomal analysis of the regenerated plantlets established a stable germplasm with $2 n=14$ bimodal chromosomes. The cost effectiveness and economic viability of the protocol has also been evaluated.
\end{abstract}

\section{Introduction}

Aloe vera L. Burm. f. (Liliaceae) has enormous demand in the medicinal and cosmetic industries. It is commonly called as 'Burn plant' believed to have originated from Africa (Natali et al. 1990). In terms of barbaloin content $A$. vera has many cultivars. We collected one such certified 'bitter' cultivar of $A$. vera from NBPGR Jodhpur, India (Fig. 1). The most important constituent of Aloe is aloin. Aloin extracted from natural sources is a mixture of two diastereomers, termed (i) Aloin A (barbaloin, an anthraquinone glycoside) and (ii) Aloin B (isobarbaloin), which have similar chemical properties (Hamman 2008). The plant has several uses in instant inhibition of pain and inflammation (Vazquez 1996), has tremendous antioxidant activity (Lee et al. 1997) it works as immunomodulators in preventing UVB-induced immune suppression of the skin (Lee et al. 1997). It also works as a curative against peptic ulcers and other

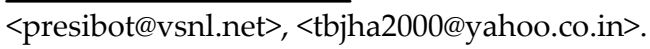


gastrointestinal malfunctions (Hamman 2008) and has a wide array of cosmetic usage.

The primary application of micropropagation has been to produce number of high quality disease free plants independent of seasonal and other environmental conditions in a comparatively smaller space from an elite germplasm (Deberg and Zimmerman 1991, Kozai et al. 1997, Levin and Vasil 1989). However, in many cases, the cost of micropropagule production precludes the adoption of the technology for large-scale commercial production. Our study concentrates on high frequency micropropagation of disease free quality plants of $A$. vera from shoot apical meristem and confirming the efficacy of the protocol by studying its cost analysis.

\section{Materials and Methods}

Plants collected from NBPGR, CAZRI, Jodhpur, India were maintained in the experimental garden of Presidency College, Kolkata (Fig. 1). The explants were washed and treated with $0.1 \% \mathrm{w} / \mathrm{v}$ solution of Bavistin for $30 \mathrm{~min}$. The explants were then treated with freshly prepared $0.1 \% \mathrm{w} / \mathrm{v}$ aqueous solution of $\mathrm{HgCl}_{2}$ for $15 \mathrm{~min}$. Explants were thoroughly washed four - five times with sterile double distilled water to remove any traces of the sterilant. MS supplemented with 3\% $\mathrm{w} / \mathrm{v}$ sucrose, $0.7 \% \mathrm{w} / \mathrm{v}$ agar, $0.25 \% \mathrm{w} / \mathrm{v}$ activated charcoal along with 2.22 - 35.58 $\mu \mathrm{M}$ BAP, 0.49 - $9.8 \mu \mathrm{M}$ IBA and $2.69-10.74 \mu \mathrm{M}$ NAA either singly or in various combinations were used. Additives like $81.4-108.58 \mu \mathrm{M}$ adenine sulphate and $5-30 \%$ coconut milk were used in various concentrations and combinations. Aloe gel was used for root induction. All the cultures were maintained in standard conditions of temperature, humidity and photoperiod. Observations were recorded every week. All experiments were repeated thrice. The regenerated plantlets were planted in a mixture of soil, sand and manure $(1: 1: 1)$. The plants were maintained under optimum conditions and kept in the green house and eventually transferred to field conditions.

Fresh young roots were taken from both the in vivo and in vitro healthy plants for chromosomal analysis and pretreated with $0.002 \mathrm{M}$ 8-hydroxyquinoline for $3 \mathrm{hr}$ at $10-12^{\circ} \mathrm{C}$ and fixed in acetic-ethanol $(1: 3)$ for overnight. The root tips were hydrolyzed in $1 \mathrm{~N} \mathrm{HCl}$ for 5 min and stained with $2 \%$ aceto-orcein (Sharma and Sharma 1990).

The experiments were set up in a randomized design. Data were analyzed by ANOVA to detect significant differences between means (Rohlf 1998). Means differing significantly were compared using DMRT at a 5\% probability level. Variability of data has also been expressed as the mean \pm standard error (SE). 


\section{Results and Discussion}

Shoot bud induction was found best in MS containing 35.5 $\mu \mathrm{M}$ BAP, $9.8 \mu \mathrm{M}$ IBA and $81.4 \mu \mathrm{M}$ adenine sulphate (Table 1). Initially $8-10$ shoot buds induced from single explant within four weeks of culture (Figs. 2A, B). Newly formed shoot buds were transferred to MS $(0.7 \%$ agar) containing $8.87 \mu \mathrm{M}$ BAP and $2.46 \mu \mathrm{M}$ IBA and $108.58 \mu \mathrm{M}$ adenine sulphate for further multiplication and

Table 1. Effect of different combinations of cytokinins and auxin on shoot bud formation in A. vera.

\begin{tabular}{cccc}
\hline $\begin{array}{c}\text { MS + 3 \% sucrose }+81.4 \mu \mathrm{M} \\
\text { adenine sulphate }\end{array}$ & $\begin{array}{l}\text { Percentage of explants } \\
\text { showing shoot bud } \\
\text { formation }\end{array}$ & $\begin{array}{c}\text { No. of shoot buds per } \\
\text { explant (mean } \pm \text { SE) }\end{array}$ \\
\hline $\begin{array}{c}\text { Conc. of BAP } \\
(\mu \mathrm{M})\end{array}$ & $\begin{array}{c}\text { Conc. of IBA } \\
(\mu \mathrm{M})\end{array}$ & $\mathbf{8 3 . 0}$ & $\mathbf{9 . 7 \pm 0 . 1 4 ^ { \mathrm { b } }}$ \\
\hline 35.5 & $\mathbf{9 . 8}$ & 73.68 & $5.5 \pm 0.16^{\mathrm{a}}$ \\
22.1 & 4.9 & 71.39 & $5.1 \pm 0.17^{\mathrm{a}}$ \\
\hline 8.87 & 2.46 & & \\
\hline
\end{tabular}

All experiments were repeated thrice. Data are represented as mean \pm SE followed by DMRT analysis $(\mathrm{p} \leq 0.05)$.

proliferation (Fig. 3). Addition of $15 \%$ coconut milk and $108.58 \mu \mathrm{M}$ Adenine sulphate enhanced bud induction per explant. Highest number $(22.0 \pm 0.14)$ of proliferated shoot buds from a single explant was also achieved in the same medium within two weeks after first subculture (Table 2, Fig. 4). The shoots were transferred to MS ( $3 \%$ sucrose) with $4.44 \mu \mathrm{M}$ BAP and 1.23 $\mu \mathrm{M}$ IBA for further proliferation (Fig. 5, Table 2). The cells of apical meristem possess a high degree of morphogenetic potential for generating plants with similar genotypic and phenotypic composition as that of the mother source, indicating these cells tend to be genetically stable. The nutrient medium and phytohormones stimulate and support the development and growth of multiple buds. Three to sixfold increase in shoot number can be achieved every four - six weeks, result in the production of countless number of quality plants from each cultured shoot meristem round the year. Ahmed et al. 2007 reported $98.96 \%$ shoot proliferation and 15.39 shoots per explant in a media combination of $2.0 \mathrm{mg} / \mathrm{l} \mathrm{BA}, 0.5 \mathrm{mg} / \mathrm{Kn}$ and $0.2 \mathrm{mg} / \mathrm{l}$ NAA. Wenping et al. (2004) and Liao (2004) reported 95.30\% shoot proliferation in a combination of BA and NAA. Whereas Aggarwal and Barna (2004) documented highest shoot multiplication in Aloe vera in MS supplemented with $1.0 \mathrm{mg} / \mathrm{l} \mathrm{BA}$ and $0.2 \mathrm{mg} / \mathrm{l} \mathrm{IBA}$. Recently, Hashemabadi and Kaviani (2008) reported maximum number of shoots around $9.67 \%$ shoots/explant in a media combination of MS supplemented with $0.5 \mathrm{mg} / \mathrm{l}$ BA and $0.5 \mathrm{mg} / \mathrm{l}$ NAA. Considering all the previous works on micropropagation in Aloe vera our protocol till date reports highest number of shoots/per explant in this particular 
Table 2. Effect of different combinations of auxin and cytokinins on shoot proliferation in A. vera.

\begin{tabular}{|c|c|c|c|c|}
\hline \multicolumn{2}{|c|}{$\begin{array}{l}\text { MS }+3 \% \text { sucrose }+15 \% \\
\text { coconut milk+ } 108.58 \mu \mathrm{M} \\
\text { adenine sulphate }\end{array}$} & \multirow{2}{*}{$\begin{array}{l}\text { Percentage of } \\
\text { explants } \\
\text { showing shoot } \\
\text { formation }\end{array}$} & \multirow{2}{*}{$\begin{array}{c}\text { No. of } \\
\text { shoots per } \\
\text { explant } \\
\text { (Mean } \pm \text { SE) }\end{array}$} & \multirow[t]{2}{*}{$\begin{array}{l}\text { Length of shoots } \\
\text { per explant } \\
\text { (Mean } \pm \text { SE) }\end{array}$} \\
\hline $\mathrm{BAP}(\mu \mathrm{M})$ & IBA $(\mu \mathrm{M})$ & & & \\
\hline 35.48 & 9.80 & 68 & $9.7 \pm 0.14^{\mathrm{a}}$ & $0.89 \pm 0.009^{a}$ \\
\hline 22.19 & 7.36 & 71 & $11.1 \pm 0.17^{a}$ & $1.04 \pm 0.018^{a}$ \\
\hline 13.32 & 4.90 & 75 & $12.3 \pm 0.14^{\mathrm{a}}$ & $1.39 \pm 0.04^{\mathrm{a}}$ \\
\hline 8.87 & 2.46 & 100 & $22.0 \pm 0.14^{c}$ & $4.20 \pm 0.03^{b}$ \\
\hline 4.44 & 0.98 & 89 & $15.7 \pm 0.20^{\mathrm{b}}$ & $1.59 \pm 0.04^{\mathrm{a}}$ \\
\hline 2.22 & 0.49 & 85 & $13.8 \pm 0.18^{b}$ & $1.2 \pm 0.05^{\mathrm{a}}$ \\
\hline
\end{tabular}

All experiments were repeated thrice. Data are represented as mean \pm SE followed by DMRT analysis $(\mathrm{p} \leq 0.05)$.

cultivar. In our protocol 22 shoot buds are obtained from a single explant which indicates the efficiency of this protocol. Proliferated shoots attained suitable size for rooting in seven - eight weeks from the time of initiation of culture. For induction of roots different concentrations of $2.45-9.8 \mu \mathrm{M}$ IBA and $2.69-10.64$ $\mu \mathrm{M}$ NAA were tried separately and we obtained $80 \%$ root induction in $2.45 \mu \mathrm{M}$ IBA and $77 \%$ root induction in $2.69 \mu \mathrm{M}$ NAA. For the first time we have used serial concentrations of Aloe vera gel as a substitute of MS to grow the in vitro Aloe shoots. To our surprise we have obtained induction of roots in all the concentrations of Aloe vera gel without addition of sucrose and growth regulators (Table 3). The highest percentage (15) of shoots that induced roots was obtained in Aloe gel (Table 3). The highest number of roots $(10.90 \pm 0.17)$ and maximum length of shoot $(3.02 \pm 0.11)$ was obtained in the same medium (Figs. 6A, B). Roots developed within two weeks after subculture. Rooting in vitro in Aloe gel is a first report of its kind and may be used in other species to see its effect. Cent per cent survival of the regenerated tissue culture raised plants was observed in field (Fig. 7). Aloe vera gel has been used as a source of functional food and as an ingredient in other food products due to presence of over 75 active ingredients like vitamins, minerals, polysaccharides and organic acids. Prior to our work no one has used Aloe gel as a complete substitute of MS salts.

Clonal fidelity of the plants was checked by chromosomal study. Chromosomal analysis of mother plant and tissue culture raised plants revealed the presence of stable diploid cells with $2 x=2 n=14$ chromosomes showing bimodal karyotype (Figs. 8, 9). 

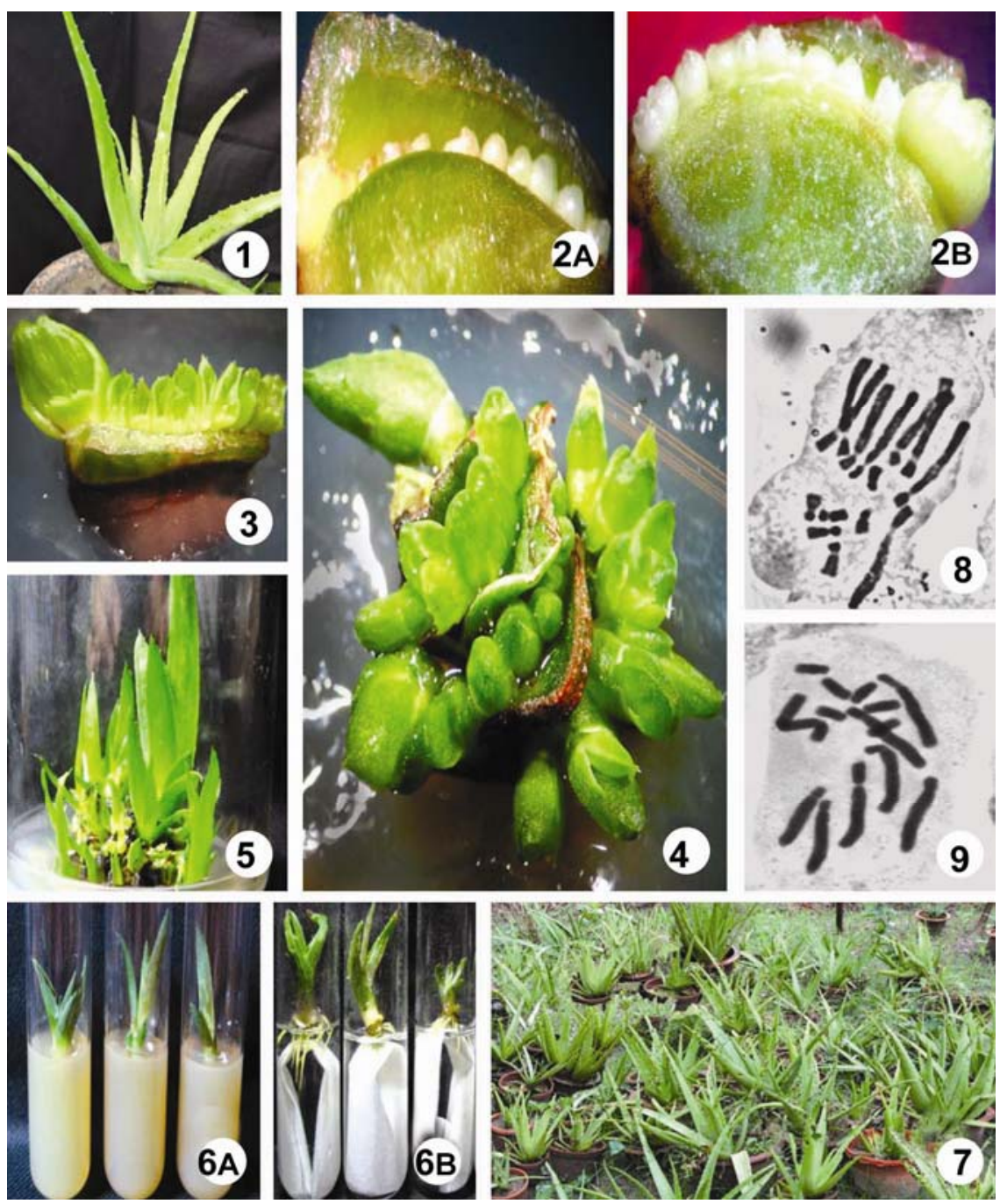

Figs. 1-9: 1. Shoot apical meristem explant for micropropagation. 2A,B. Initial induction of shoot buds. 3. Induced shoot buds after five - six weeks. 4. Highest number of shoot bud induction (22). 5. Multiple shoot bud induction and proliferation. 6A. In vitro grown shoots of A. vera in Aloe gel for induction of rooting. 6B. Highest number of roots induced (10.9 \pm 0.17$)$. 7. Micropropagated Aloe plants growing in field conditions. 8 - 9. Somatic metaphase plates showing $2 n=14$ chromosomes of the mother plant and one of the tissue culture derived plants, respectively.

The described protocol seems to be technologically suitable for micropropagation of $A$. vera. In low cost technology cost reduction is achieved by improving process efficiency and better utilization of resources. Our protocol reports highest number (22) of shoot bud induction and proliferation from a single explant. We have analyzed the production cost of 22 complete plants from culture initiation to hardening and field transfer. The detailed cost analysis 
presented in Table 4 shows that at the present market rate the cost of 22 regenerated plants in one jam bottle does not exceed Rs. 58.47. Keeping in mind that jam bottles can be recycled many times, price of one tissue culture plant

Table 3. Effect of IBA, NAA and Aloe gel on root induction in A. vera shoots.

\begin{tabular}{cccccc}
\hline $\begin{array}{c}\text { Type and conc. of } \\
\text { PGR's }(\mu \mathrm{M}) \text { and } \\
\text { Aloe gel }(\%)\end{array}$ & $\begin{array}{c}\text { Medium } \\
\text { used }\end{array}$ & $\begin{array}{c}\text { Percentage of } \\
\text { shoots showing } \\
\text { root formation }\end{array}$ & $\begin{array}{c}\text { No. of roots per } \\
\text { shoot } \\
(\text { Mean } \pm \text { SE) }\end{array}$ & $\begin{array}{c}\text { Length of root } \\
(\mathrm{cm}) \text { per shoot } \\
(\text { Mean } \pm \text { SE) }\end{array}$ \\
\hline IBA & 2.45 & MS & 80.00 & $3.9 \pm 0.22^{\mathrm{a}}$ & $1.81 \pm 0.02^{\mathrm{b}}$ \\
& 4.90 & & 78.20 & $3.9 \pm 0.22^{\mathrm{a}}$ & $1.92 \pm 0.05^{\mathrm{b}}$ \\
& 7.35 & & 75.68 & $3.1 \pm 0.22^{\mathrm{a}}$ & $2.53 \pm 0.16^{\mathrm{b}}$ \\
& 9.80 & & 67.00 & $3.1 \pm 0.22^{\mathrm{a}}$ & $2.02 \pm 0.04^{\mathrm{b}}$ \\
NAA & 2.69 & MS & 77.69 & $3.0 \pm 0.19^{\mathrm{a}}$ & $1.51 \pm 0.03^{\mathrm{a}}$ \\
& 5.37 & & 73.21 & $3.9 \pm 0.17^{\mathrm{a}}$ & $2.55 \pm 0.03^{\mathrm{b}}$ \\
& 8.06 & & 56.38 & $2.6 \pm 0.25^{\mathrm{a}}$ & $1.92 \pm 0.013^{\mathrm{b}}$ \\
& 10.74 & & 66.79 & $3.2 \pm 0.13^{\mathrm{a}}$ & $2.89 \pm 0.04^{\mathrm{c}}$ \\
& 100 & Nil & 83.62 & $5.1 \pm 0.17^{\mathrm{ab}}$ & $1.59 \pm 0.06^{\mathrm{b}}$ \\
& 50 & & 88.22 & $8.8 \pm 0.13^{\mathrm{c}}$ & $2.78 \pm 0.06^{\mathrm{c}}$ \\
& 25 & & 100.00 & $10.9 \pm 0.17^{\mathrm{d}}$ & $3.02 \pm 0.11^{\mathrm{c}}$ \\
& 15 & & 95.10 & $8.0 \pm 0.19^{\mathrm{c}}$ & $2.91 \pm 0.03^{\mathrm{c}}$ \\
& 10 & & 88.45 & $5.8 \pm 0.18^{\mathrm{b}}$ & $2.01 \pm 0.03^{\mathrm{b}}$ \\
\hline
\end{tabular}

All experiments were repeated thrice. Data are represented as mean \pm S.E followed by DMRT analysis $(\mathrm{p} \leq 0.05)$

Table 4. Cost analysis of 22 in vitro regenerated plantlets of $A$. vera in Rupees.

\begin{tabular}{lr}
\hline $0.1 \%$ bavistin $(50 \mathrm{ml})$ & Rs. 0.01 \\
$0.1 \% \mathrm{HgCl}_{2}(50 \mathrm{ml})$ & 0.39 \\
MS basal medium $(200 \mathrm{ml})$ [Himedia] & 11.0 \\
Sucrose $(3 \%)$ & 2.40 \\
Activated charcoal $(0.025 \%)$ [Merck] & 0.187 \\
PGRs. (BAP $48.79 \mu \mathrm{M}+\mathrm{IBA} 13.49 \mu \mathrm{M})[$ Sigma] & 0.067 \\
Adenine sulphate $(189.98 \mu \mathrm{M})$ & 0.114 \\
Agar $(0.7 \%)(300 \mathrm{ml}$ media) & 8.40 \\
One jam bottle with cap (Recurring) & 11.00 \\
Miscellaneous expenses & 25.00 \\
\hline Total cost & Rs. 58.47 \\
The cost of a single plant is estimated around & Rs. 2.65
\end{tabular}

${ }^{*}$ Cost of chemical ingredients (Sigma-Aldrich) according to the current price list (2008-09).

produced through our protocol cannot be over Rs. 2.65, whereas the current market price of one single Aloe plant is Rs. 5. Use of Aloe gel for root induction may further reduce the cost price. The efficient, reproducible and cost effective 
protocol developed in our laboratory can be adopted for commercialization of Aloe cultivation. The study of economics and cost effectiveness of the protocol gives an added advantage to the micropropagation industry.

\section{References}

Aggarwal D and Barna KS (2004) Tissue culture propagation of elite plant of Aloe vera Linn. J. Biochem. Biotech. 13: 77-79.

Ahmed S, Kabir AH, Ahmed MB, Razvy MA and Ganesan S (2007) Development of rapid micropropagation method of Aloe vera L. Sjemenarstvo 24: 2 121-128.

Debergh PC and Zimmerman RH (1991) Micropropagation: Technology and Application, Kluwer, Dordrecht.

Hashemabadi D and Kaviani B (2008) Rapid micro-propagation of Aloe vera L. via shoot multiplication. African J. Biotech. 7(12): 1899-1902.

Hamman Josias H. (2008) Composition and application of Aloe vera leaf gel. Molecules 13: 1599-1616.

Kozai T, Kubota C and Jeong BR (1997) Environmental control for the large scale production of plants through in vitro techniques. Plant Cell, Tissue \& Organ Cult. 51: 49-56.

Lee CK, Han SS, Mo YK, Kim RS, Chung MH, Park YI, Lee SK and Kim YS (1997) Prevention of ultraviolet radiation-induced suppression of accessory cell function of Langerhans cells by Aloe vera gel components. Immunopharmacology Oct 37(2-3): 153-162.

Levin R and Vasil IK (1989) Progress in reducing the cost of micropropagation IAPTC Newsl. 59: 2-12.

Liao Z, Chen M, Tan F, Sun X and Tang K (2004) Micropropagation of endangered Chinese Aloe. PCTOC 76(1): 83-86.

Natali L, Sanchez IC and Cavallini A (1990) In vitro culture of Aloe barbadensis Mill: Micropropagation from vegetative meristems. PCTOC 20: 71-74.

Rohlf FJ (1998) Numerical taxonomy and multivariate analysis system. Version 2.0. New York: Exeter Publications.

Sharma AK and Sharma A (1990) Chromosome Techniques: Theory and practice, Third Edition. Butterworth and Co. Limited, London

Vazquez B, Avila G, Segura D and Escalante B (1996) Anti-inflammatory activity of extracts from Aloe vera gel. J. Ethnopharmacol. 55(1): 69-75.

Wenping D, Shi D, Xu L, Yu G and Mili W (2004) A preliminary study on the induction and propagation of adventitious buds for Aloe vera L. Southeast China J. Agric. Sci. 17(2): 224-227. 